\title{
Alternatif Penanganan Dampak Pandemi Covid-19 Melalui Sosialisasi dan Pelatihan Teknologi
}

\author{
Indriyani $^{1}$, Paula Dewanti ${ }^{2}$, Komang Bhargo Bhaskara ${ }^{3}$ \\ 1,2,3 ITB Stikom Bali, Denpasar, Indonesia \\ 1indriyani@stikom-bali.ac.id, ${ }^{2}$ paula_dewanti@stikom-bali.ac.id, ${ }^{3}$ bhargobhaskara9@gmail.com
}

\begin{abstract}
These community service activities were intended to ease the burdens on people impacted by the Covid-19 pandemic, especially from a financial standpoint. The implementation process was carried out offline and online, utilizing the technology. The event begins with a technology dissemination talk, an education on how to grow crops through the hydroponic method, then continued with a technology education in the form of Design classes, Webinars with the topic of learning and business in the new normal era, and closed with ceremonial, photos sessions, along with the delivery of donations.
\end{abstract}

Keywords: Community Service, Covid-19, Economy, New Normal, Technology.

\begin{abstract}
Abstrak
Kegiatan pengabdian masyarakat ini bertujuan untuk meminimalisir beban masyarakat yang terkena dampak pandemi Covid-19 terutama dari sisi ekonomi. Proses pelaksanaan kegiatan dilakukan secara offline dan online dengan menggunakan teknologi. Pengabdian masyarakat diawali dengan kegiatan sosialisasi teknologi, edukasi cara bercocok tanam melalui metode hidroponik kemudian dilanjutkan dengan edukasi teknologi berupa kelas desain, webinar dengan topik pembelajaran dan bisnis di era new normal hingga ditutup dengan ceremony dan foto bersama penyerahan bantuan sosial.
\end{abstract}

Kata Kunci: Pengabdian Masyarakat, Teknologi, Ekonomi, Covid-19, New Normal.

\section{A. PENDAHULUAN}

Pandemi Covid-19 telah memberikan dampak yang nyata bagi masyarakat. Sektor kesehatan merupakan sektor utama yang terdampak. Namun, ada dua sektor lainnya yang perlu menjadi perhatian di antaranya sektor ekonomi dan pendidikan (Siahaan, 2020). Peningkatan status Covid-19 sebagai pandemi memberikan dampak besar terhadap aktivitas keseharian masyarakat.

Social distancing merupakan perilaku menjaga jarak minimal dua meter dari orang di sekitarnya, menghindari tempat umum, dan menjauhi keramaian (CDC, 2020). Melalui cara tersebut, diharapkan penyebaran virus akan berkurang. Sejumlah kebijakan protokol kesehatan telah diterapkan, namun, hal tersebut menimbulkan masalah baru. Menurut Sumarni (2020), di sisi ekonomi aktivitas jual beli menjadi cukup terhambat karena pembatasan interaksi, sebagian besar aktivitas harus dilakukan dari rumah. Begitu pula dari sisi pendidikan, Aji (2020) bahkan berpendapat bahwa dampak psikologis hingga berkurangnya kualitas peserta didik dapat muncul apabila terdapat gangguan dalam proses belajar mengajar.

Pembatasan interaksi berupa physical atau social distancing tetap harus dilaksanakan, Herdiana (2020), sementara di sisi lain, aktivitas pembelajaran juga harus terus berjalan. Oleh karena itu Almarzooq dkk. (2020) berpendapat bahwa penggunaan metode virtual adalah pilihannya, masalah teknis memang sangat mungkin terjadi, namun masih dapat dikelola dengan baik ketika pengguna telah terbiasa memanfaatkan teknologi virtual.

Menurut Kisworo (2014), pengabdian masyarakat dalam Pasal 1 ayat 9 Undang-Undang No. 12 Tahun 2012 tentang Pendidikan Tinggi, merupakan bagian dari Tridharma Perguruan Tinggi. Sehingga dosen dan mahasiswa sebagai bagian dari sivitas akademika, berkewajiban untuk menggunakan ilmu pengetahuan dan teknologi yang ada demi mencerdaskan kehidupan bangsa dan meningkatkan 
kesejahteraan masyarakat. Sebagai generasi muda, mahasiswa juga diharapkan memiliki kekuatan moral dan menjadi kontrol sosial (Mona, 2018).

Dengan alasan itulah, pengabdian masyarakat ini terlaksana. Mulai dari sosialisasi pemanfaatan teknologi di sektor ekonomi dan pendidikan, transfer skill melalui edukasi cara bercocok tanam dengan metode hidroponik untuk menunjang ekonomi, membuka kelas desain Canva dan EasyWorkship untuk menambah keterampilan remaja, menyelenggarakan webinar dan diakhiri dengan pembagian bantuan sosial. Kegiatan-kegiatan tersebut bertujuan untuk mengurangi beban masyarakat Desa Pengotan, Kecamatan Bangli, Kabupaten Bangli yang terdampak pandemi Covid-19.

Meski ekonomi sedang terpuruk, Rohmah (2020) meyakini bahwa masih ada peluang usaha dalam skala besar maupun kecil. Kami mendukung pendapat tersebut dengan menggali lebih jauh tentang fungsi teknologi yang dapat dimanfaatkan untuk menunjang aktivitas ekonomi dan pendidikan di Desa Pengotan.

\section{B. PELAKSAAN DAN METODE}

Waktu pelaksanaan kegiatan pengabdian masyarakat dimulai sejak tanggal 6 - 20 Desember 2020 . Pengabdian masyarakat diisi dengan kegiatan edukasi teknologi secara luring dan daring, penyerahan bantuan sosial, penyerahan plang nama Beji dan Pura serta pelaksanaan ceremony puncak acara di hari terakhir.

Sebanyak 22 ORMAWA terlibat dalam proses penyelenggaraan pengabdian masyarakat di Desa Pengotan, Kecamatan Bangli, Kabupaten Bangli. Masing-masing memiliki peranan, 16 di antaranya bertugas untuk terjun ke lapangan untuk mendata kebutuhan dan potensi di setiap Banjar Desa. Sedangkan ORMAWA lainnya bertugas untuk memproduksi foto dan video, mengecek dan melakukan inovasi terhadap website desa untuk mempromosikan aset dan kualitas desa tersebut.

\section{HASIL DAN PEMBAHASAN}

Kegiatan pengabdian masyarakat dimulai sejak 6 Desember 2020 dengan konsep pengajaran ilmu teknologi dengan bantuan ahli dari ITB STIKOM Bali berupa sosialisasi aplikasi teknologi di masa new normal, teknologi bertani secara hidroponik dan penyerahan bantuan sembako pada masyarakat Kampung Bugis. Aktivitas ini diawali oleh Unit Kegiatan Mahasiswa Moslem Community of STIKOM Bali (UKM MCOS).

Kegiatan juga berlangsung pada tanggal 10 Desember 2020 di Panti Asuhan Kristen 400 Baith-EL, Klungkung yang dilaksanakan oleh UKM PMK (Persaudaraan Mahasiswa Kristen) bersama dengan BEM. Pengabdian masyarakat ini diisi dengan pembagian sembako serta pelaksanaan Kelas Desain Canva dan EasyWorkship bersama anak-anak panti asuhan.

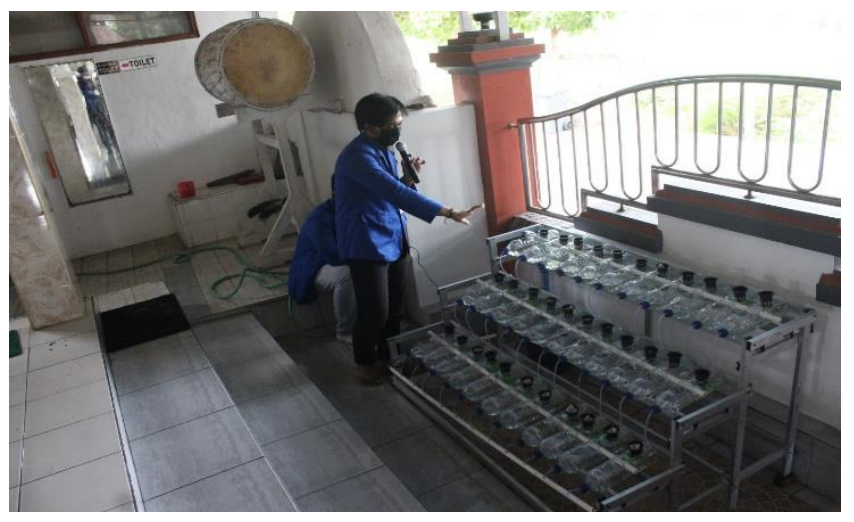

Gambar 1. Edukasi Cara Bercocok Tanam dengan Metode Hidroponik 


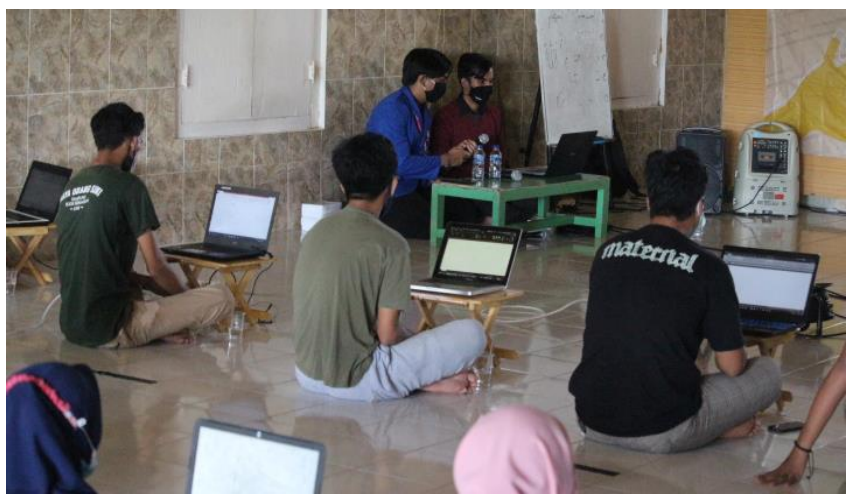

Gambar 2. Kelas Desain Canva dan EasyWorkship

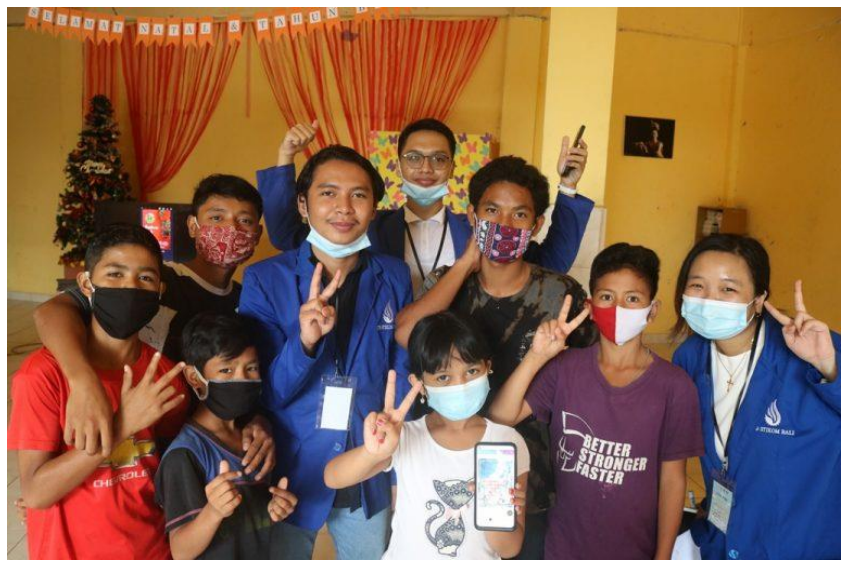

Gambar 3. Foto Bersama di Panti Asuhan

Berlanjut pada tanggal 12 hingga 13 Desember 2020, pengabdian masyarakat oleh ITB STIKOM Bali menggelar acara webinar bagi para pengajar tingkat SMP dan SMA. Meski begitu, antusiasme peserta tidak hanya datang dari para pengajar di Bali, namun juga dihadiri oleh peserta dari beberapa wilayah di Indonesia.

Tema yang diusung pada webinar tersebut ialah "Pemanfaatan Teknologi pada Media Pembelajaran" oleh Ibu Luh Made Yulyantari, S.Kom., M.Pd. berikut materi kedua yakni "Pemaksimalan Media Pembelajaran Daring di Era New Normal". Pada hari selanjutnya, topik "Presentasi yang Inspiratif" oleh Bapak I Gede Harsemadi, S.Kom., M.T. cukup menarik perhatian para peserta yang hadir melalui aplikasi panggilan video Zoom.

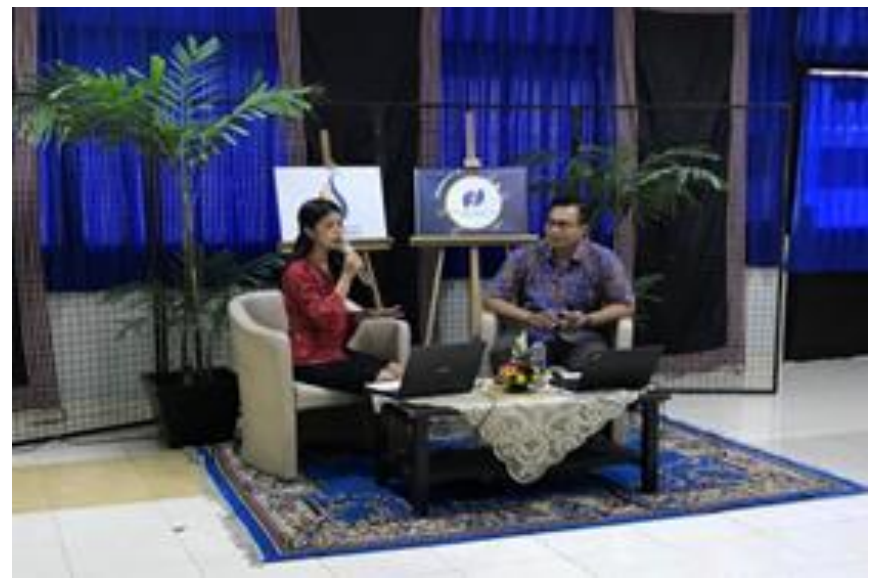

Gambar 4. Webinar dengan Materi Teknologi

Kegiatan pengabdian masyarakat di masa pandemi ini memang cukup beragam. Selain memberikan bantuan sembako dan melaksanakan program edukasi, pada tanggal 19 Desember 2020, kegiatan bakti 
sosial gabungan bersama UKM Kerohanian Mahasiswa Hindu Budha (KMHD) melakukan penyerahan papan nama Beji di Desa Pengotan. Secara simbolis, plang Beji tersebut diberikan kepada Pemangku Kura dan Kelian Banjar kemudian dilanjutkan dengan penyerahan plang nama Pura hingga kerja bakti membersihkan area Beji dan Pura.

Setelah aneka macam kegiatan dilaksanakan, tibalah pada acara puncak pengabdian masyarakat dan bakti sosial gabungan berupa ceremony penyerahan bantuan sosial dan bantuan kedinasan. Kegiatan ini dilaksanakan pada 20 Desember 2020 yang diawali dengan penyerahan paket bantuan sosial secara simbolis. Bantuan tersebut berasal dari pengumpulan donasi via akun kitabisa.com yang diorganisir oleh para mahasiswa ITB STIKOM. KitaBisa (2020) merupakan media untuk melakukan donasi dan galang dana via online. Pada ceremony ini pula dilaksanakan pemotongan pita sebagai simbol peresmian plang nama lembaga desa oleh Bapak I Kadek Yastawa selaku Kepala Desa bersama perwakilan manajemen ITB STIKOM Bali, Ibu Ni Luh Putri Srinadi, SE., MM. Kom., selaku Wakil Rektor 2.

Puncak ceremony dilanjutkan dengan sesi pemutaran video promosi yang telah diproduksi oleh para mahasiswa. Kemudian diikuti dengan sosialisasi bisnis yang disampaikan oleh dosen kampus dan Inkubator Bisnis atau INBIS ITB STIKOM Bali. Materi pertama dengan topik "Scale Up Usaha" disampaikan oleh Bapak I Gede Bintang Arya Budaya, dan pembahasan kedua berupa "Media Sosial sebagai Bekal Kemajuan di Era Industri 4.0" diulas secara lengkap oleh Ibu Ni Putu Putri Ayu Wijayanthi S. Kom., M.M.

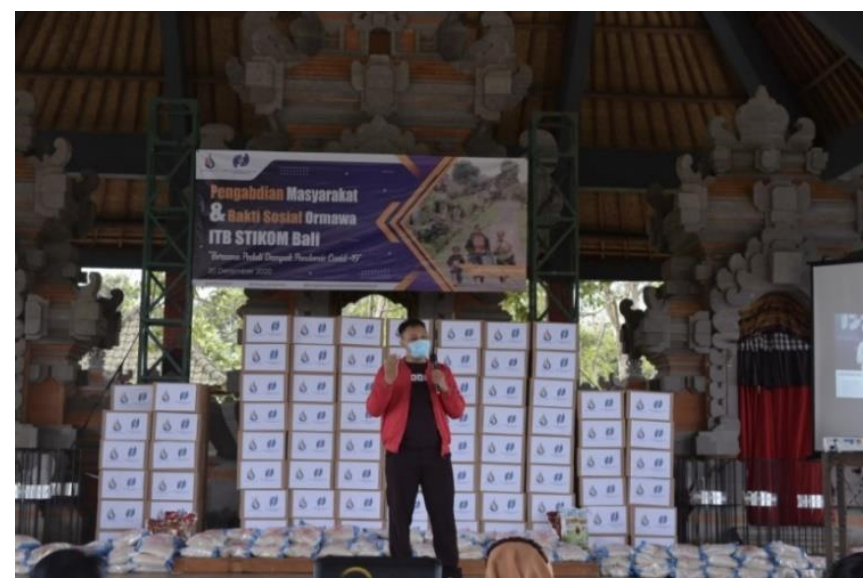

Gambar 5. Sosialisasi oleh INBIS ITB STIKOM Bali kepada Masyarakat mengenai Scaling Up Usaha/UMKM di Desa Pengotan oleh I Gede Bintang Arya Budaya

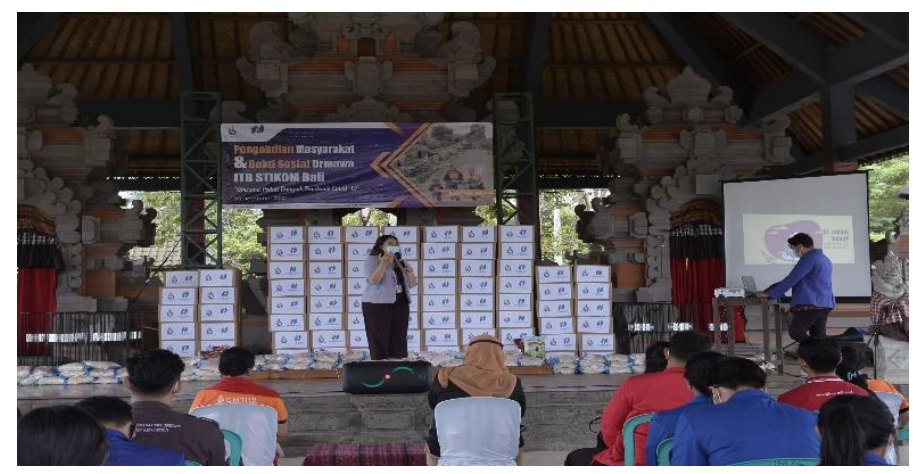

Gambar 6. Sosialisasi kepada Masyarakat dan Mahasiswa ITB STIKOM Bali dengan Tema Media Sosial sebagai Bekal di Era Industri 4.0 oleh, Ni Putu Putri Ayu Wijayanthi, S.Kom., M.M. 


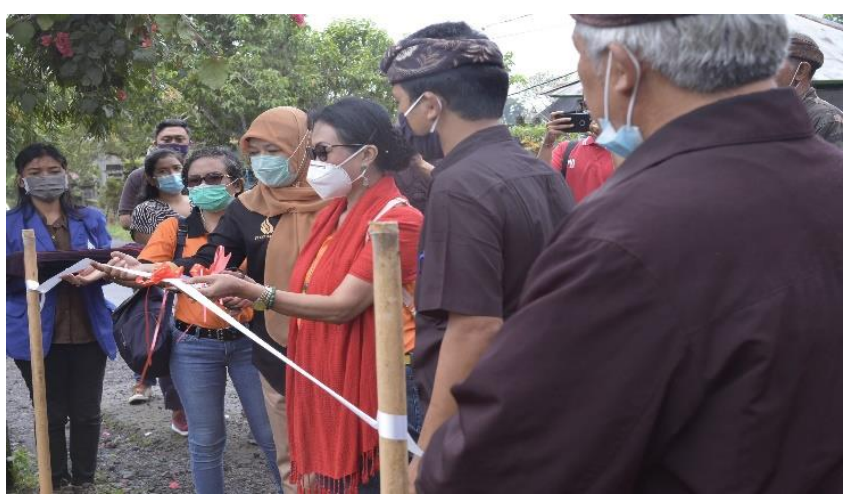

Gambar 7. Persemian Plang Lembaga Desa dengan Potong Pita oleh Wakil Rektor 2 ITB STIKOM Bali (Tengah) di dampingi oleh Direktur Akademik dan Kemahasiswaan (Kiri) serta Kepala Desa Pengotan (Kanan)

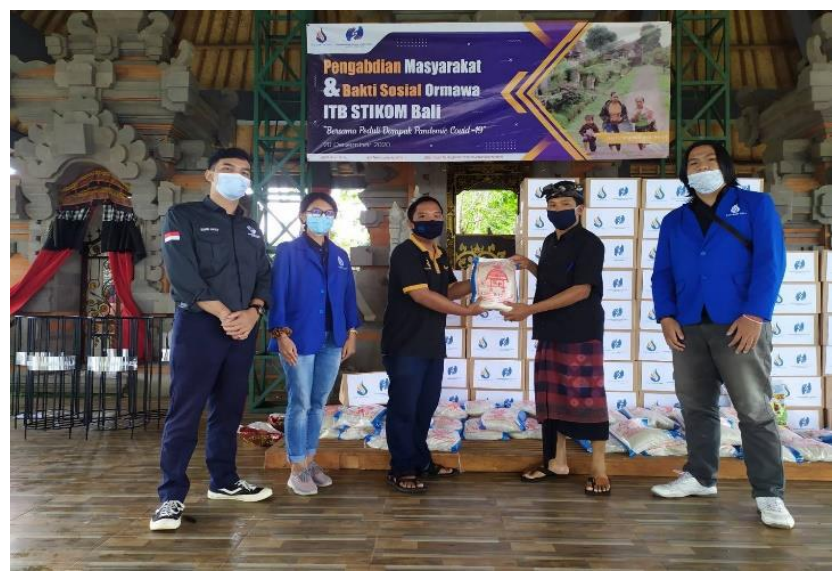

Gambar 8. Penyerahan Bantuan Sosial

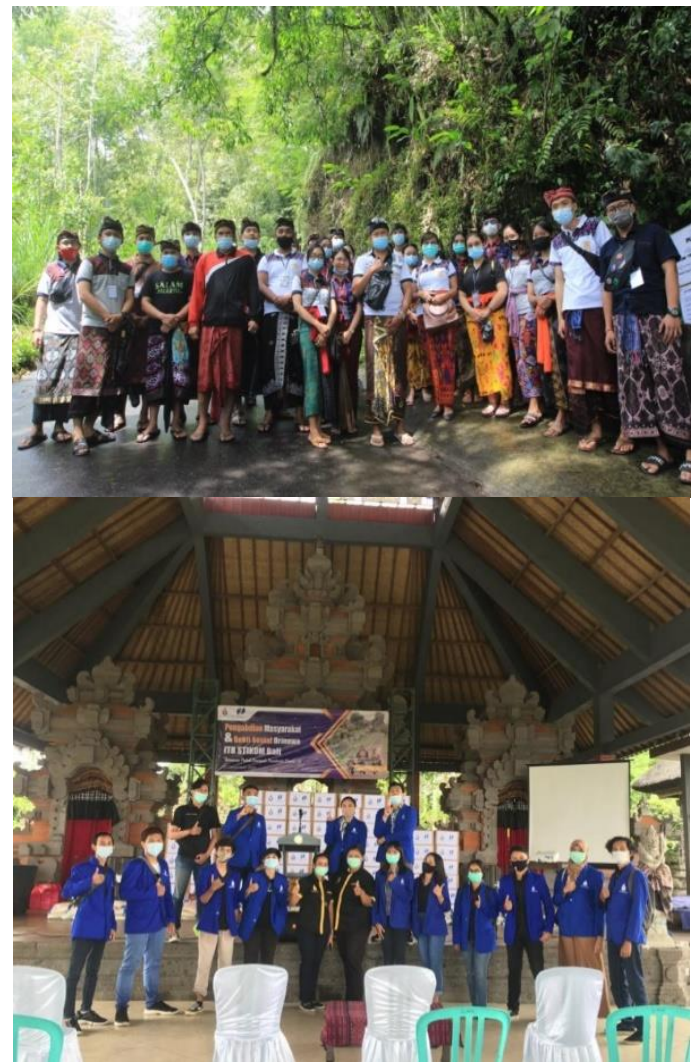

Gambar 9. Foto Bersama 
Menjelang akhir ceremony, perwakilan ORMAWA STIKOM Bali juga memberikan penjelasan mengenai pengembangan potensi desa setelah memaparkan hasil inovasi website. Acara kemudian ditutup dengan sesi foto bersama. Setelah ceremony selesai dilaksanakan, dosen pendamping bersama dengan Kelian Banjar memberikan bantuan dari rumah ke rumah dengan mengutamakan para lansia.

Berdasarkan pemaparan rangkaian kegiatan tersebut, pengabdian masyarakat yang telah dilangsungkan dapat berjalan dengan lancar. Kepedulian yang dirangkum dengan aktivitas edukasi, pembagian bantuan sosial serta pemberian plang nama Beji serta Pura menjadi wajah pengabdian yang mampu sedikit meringankan beban masyarakat.

\section{PENUTUP}

\section{Simpulan}

Pelaksanaan kegiatan pengabdian masyarakat berjalan sesuai harapan. Dimulai dari sosialisasi pemanfaatan teknologi di era new normal, edukasi cara bercocok tanam melalui metode hidroponik, penyelenggaraan kelas desain, penyelenggaraan webinar dengan topik pembelajaran dan bisnis di era new normal kemudian ditutup dengan ceremony dan foto bersama penyerahan bantuan sosial.

\section{Saran}

Bagi para mahasiswa yang telah mengikuti kegiatan bisa berperan aktif mengembangkan website desa berdasarkan potensi yang ada. Sehingga memunculkan inovasi berbasis teknologi. Selain terbantu secara ekonomi, melalui kegiatan ini pula peran edukasi-edukasi teknologi dapat dimanfaatkan oleh masyarakat setempat untuk menunjang ekonomi. Adanya PKM sebagai salah satu komponen Tri Darma Perguruan Tinggi, para akademisi dapat berperan aktif dalam tanggap darurat di masyarakat sekaligus mengamalkan keilmuan.

\section{Ucapan Terima Kasih}

Penulis mengucapkan terima kasih kepada ORMAWA ITB STIKOM, Inkubator Bisnis atau INBIS ITB STIKOM Bali, UKM MCOS, UKM PMK (Persaudaraan Mahasiswa Kristen), Badan Eksekutif Mahasiswa (BEM) ITB STIKOM Bali, serta P2M ITB STIKOM Bali atas waktu dan kesempatan yang telah disediakan sebagai dosen pendamping dalam kegiatan Pengabdian Masyarakat dan Bakti Sosial ORMAWA ITB STIKOM Bali 2020 di Desa Pengotan, Kecamatan Bangli.

\section{E. DAFTAR PUSTAKA}

Aji, R. H. S. (2020). Dampak Covid-19 pada Pendidikan di Indonesia: Sekolah, Keterampilan, dan Proses Pembelajaran. SALAM: Jurnal Sosial dan Budaya Syar-i, 7(5), 395-402. https://doi.org/10.15408/sjsbs.v7i5.15314

Almarzooq, Z. I., Lopes, M., \& Kochar, A. (2020). Virtual Learning During the COVID-19 Pandemic: A Disruptive Technology in Graduate Medical Education. Journal of the American College of Cardiology, 75(20), 2635-2638. https://doi.org/10.1016/j.jacc.2020.04.015

CDC. (2020). Social Distancing, Quarantine, and Isolation. CDC.gov. https://www.cdc.gov/coronavirus/2019-ncov/prevent-getting-sick/socialdistancing.html

Herdiana, D. (2020). KONSTRUKSI KONSEP SOCIAL DISTANCING DAN LOCKDOWN DALAM PERSPEKTIF KEBIJAKAN PUBLIK. Inovasi Pembangunan: Jurnal Kelitbangan, 8(02), 107. https://doi.org/10.35450/jip.v8i02.181

Kisworo, M. W. (2014). Proposal Visi Misi Rektor Perbanas 2014-2018. https://dosen.perbanas.id/wpcontent/uploads/2014/08/Proposal-Visi-Misi-Rektor-Perbanas-2014-2018.pdf

KitaBisa. (2020). Galang Dana Sekarang. https://kitabisa.com/about-us

Mona, L. (2018). MENGEMBANGKAN 'PERSONAL SOCIAL RESPOSIBILITY (PSR)' DALAM MEMBANGUN KARAKTER MAHASISWA. Journal Acta Diurna, 14(2), 30-47. https://doi.org/10.20884/1.actadiurna.2018.14.2.1344

Rohmah, S. N. (2020). Adakah Peluang Bisnis di Tengah Kelesuan Perekonomian Akibat Pandemi Corona? 'ADALAH: BULETIN HUKUM \& KEADILAN, 4(1), 63-74. https://doi.org/10.15408/adalah.v4i1.15448

Siahaan, M. (2020). Dampak Pandemi Covid-19 Terhadap Dunia Pendidikan. Jurnal Kajian Ilmiah, 1(1), 73-80. https://doi.org/10.31599/jki.v1i1.265

Sumarni, Y. (2020). Pandemi Covid-19: Tantangan Ekonomi dan Bisnis. Al-Intaj : Jurnal Ekonomi dan Perbankan Syariah, 6(2), 46-58. https://doi.org/http://dx.doi.org/10.29300/aij.v6i2.3358 